\title{
A critical analysis of tithe and seed sowing on contemporary Christianity in Nigeria
}

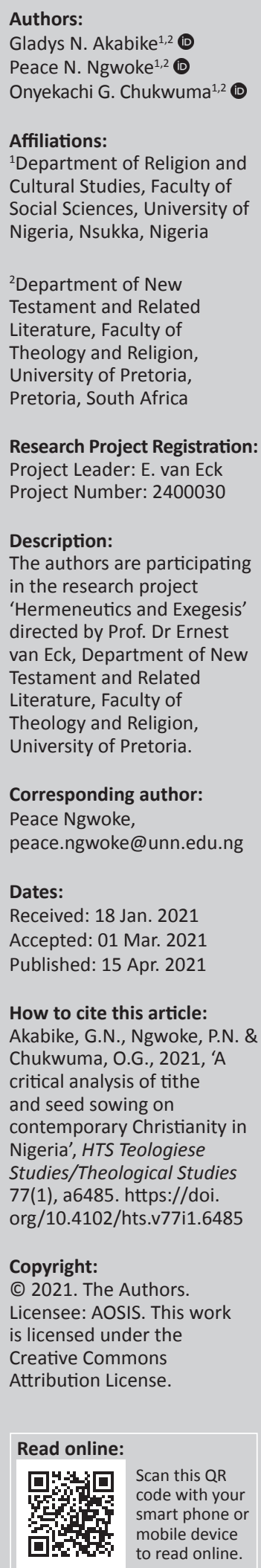

The issues of tithes and seed sowing have taken a centre stage in contemporary Christianity in Nigeria amongst the preachers. Many a times, it is assumed that tithes and seed sowing are requirements for salvation, prosperity and total well-being of the members. Making many to believe that Christianity is a money-venture business, one can succeed if he knows how to hoodwink the gullible. Many have been deceived that by parting with a substantial amount of money in the name of sowing seed, their problems would be solved. Unfortunately, the person's problem may remain the same or even be compounded. This research study evaluates the activities, attitudes and their inordinate ambitions. It examines the impact of tithe and seed sowing on Christianity in Nigeria. The research method adopted for this work is the qualitative, phenomenological method. The study observed that the value of tithe and seed sowing has changed from what is prescribed in the Bible to what is preached on the pulpits. The research study recommends amongst other things, that these preachers should preach the gospel with decorum as it were in the Bible so that its influence on Nigerians will bring about a reduction in crime, corruption and other immoral activities in Nigeria.

Contribution: The article is focused on the issues of tithes and seed sowing. It underscores the fact that the message of tithe and seed sowing has become a means of siphoning members and enriching the preachers. It further reveals its negative and positive impacts such as, the promotion of corruption and fraud in the church and society, contribution to the decline of morality in the church and the society, increasing crime rate and increasing poverty rate in Nigeria among others.

Keywords: Christianity; preachers; seed sowing; tithe; Nigeria.

\section{Introduction}

The tithe and seed sowing in Christianity are phenomena that have generated an intense debate from scholars around the globe. They are subjects of discourse, in that many have tried to understand why so much emphasis is laid on them. The debate mostly is not whether tithe and seed sowing is biblical. Rather, it is the application of these by men and women of God in the contemporary society, which is the problem.

The success of these men of God in emphasising on tithe, seed sowing and other means of achieving their aims is chiefly attributed to people's outlook on life. Generally, Africans live in a dual world - spiritual and physical. The world view of people most times determines their response to a certain situation in life. For instance, Igbo world view is principally a world of two interacting realities - the spiritual and material, each impinging on the other (Ekwunife 1990). Peoples' beliefs and practices are built on the theory that behind visible things of this world are invisible beings that we called God, gods, ancestors and so on. These invisible beings seemed to direct and determine the affairs of this world and even affect man for good or evil. Based on this, the belief in the law of causation is very paramount to Africans and is one of the reasons why Africans are said to be religious in all aspect of their lives. They want to know the reason why things are not working to their expectations in life, and hence, there is a quest for a solution by any means. This is because of the limited nature of man who always feels insecure amidst mysterious forces he experiences around him (Ndiokwere 1990). Thus, this gives room for some men of God to lay more emphasis on the psychological exploitation of the people by making them believe that their problems were evidence of not paying tithe or sowing seed in the church. This assertion is supported by Ngwoke (2021:121) who posits that 'some religious leaders, mostly from the church, manipulates their adherents by extorting money from them in the name of giving to God to be able to receive from God'. 
In addition, people have not understood that in certain situations, science can be the ultimate solution to the problem of life. The idea that through empirical means, answers to their problem will be found, especially in the area of ailments, is still a mirage to some. This is because of many factors belief system, ignorance, poverty, and socio-economic situation in the entire African continent. Nigeria being part of this continent has not fared better in this belief system. People are always in search of a solution to their problems.

More so, the Nigerian government, in all aspects, has not lived up to its responsibility of providing means of succour to the people. People are being pauperised by the government. The unemployment rate in the country is a cause of worry to the discerning mind. The margin of gap between the rich and the poor is wide. Whilst the majority of people are grappling with the uncertainty of finding daily food to eat, others are swimming in affluence based mostly on the money that could have been used to provide basic amenities for the populace.

When the expectation of some people is not met, especially after trying all means to succeed have failed, the only hope is to take solace in the fact that religion is the last hope. In order to actualise their dreams, they set out to search for the solution, which most of the time landed some in the hands of these men of God in Christianity who depend on the credulity of the members to achieve their ambition.

Consequently, Nigerian men and women of God tap into this mystery to construct anxiety-reducing sermon to allay the fear and tension that come with the conditions of the members. The preaching promises heaven on earth, blissful success even when one is not working and freedom from all shackles of life, including salvation without one being righteous or holy (Ademiluka 2020:287; Diara, Onukwufor \& Uroko 2020:1). Thus, they make the people to believe that a person's blessing is directly dependent on the level of seed one sow in the lives and ministries of the anointed men of God (Asamoah-gyadu 2018:14). Unfortunately, oftentimes, some of these religious leaders ride on the gullibility of naïve people to spread their wings of greed, wickedness, selfishness and avarice.

In order to win the minds of the unsuspecting members, they fashion out ways to convince and cajole the members to absorb whatever comes out of their mouths as a gospelinspired word of God. This they do by framing contextual messages in which the word of God is twisted to suit their emotion, and at the same time, confuse the members more in believing that the pastors are the oracles of God or God's vicar on earth. In framing the word of God (Fairclough 2001):

[E]xplicit elements of a text lead the text producer to textualize the world in a particular way, more so, in a way that leads the readers to interpret in a manner intended by the text producer. (p. 85)

This is the bane of Nigerian Christian preachers. What comes out of the mouths of these men and women of God are framed messages that they use to sweet-tongue the members into believing that all are from God. For instance, II Samuel 24:24 Amplified Version (AMP), which says '... I will not offer burnt offerings to the Lord my God which cost me nothing', is always used by these preachers to drag home to their members that one must pay tithe and sow seeds that will provoke God into action. The prosperity preachers (Appau \& Mabefam 2020):

$[E]$ ncourage believers to give more money to God (the church) to engender God's blessings and that without God's blessings ... any individual agency or structural attempt to acquire material wealth will be futile and bring only more sorrow. (p. 251)

Thus, they make adherents believe that sowing seed will solve their problems, as the seed will function as a sacred ritual to attract God's blessings. This is a clear case of juxtapositioning of different messages that highlight the inter-textual nature of the messages from these preachers. All these are survival strategies fashioned out against the innocent people who are in search of a solution to the myriad of problems confronting them daily.

This research article, therefore, examines the activities, attitude and inordinate ambition of the men and women of God in contemporary Nigeria, with the view of unravelling the factors responsible for their inordinate ambition. It will also explore the positive and negative implications of tithe and seed sowing on Contemporary Christianity in Nigeria, with the view of alerting the danger this portends to Christianity. Thus, this article will underscore the fact that the message of tithe and seed sowing by some of the Christian preachers has become a means of siphoning the merge income of the members and enriching the preachers. At this junction, it will be useful to conceptualise the terms tithe and seed sowing.

\section{Conceptualisation of terms Tithe}

The first mention of the word tithe is in Genesis where Abraham honoured Melchizedek, the king of Salem, the priest of Most High God, with one-tenth of his war bounties (Gn 14:20). Tithe is a biblical injunction by God, which makes one forfeit one-tenth of his or her annual harvest income for the upkeep of God's temple, including those working in the house of God. The purpose, as evidenced in the Bible, is to provide means of livelihood for the levities that have no inheritance amongst the Israelites (Nm 18). Also, it is for blessing and increasing one's barn in return for obedience (Ml 3:8-10).

However, in the New Testament era, the word tithe is not a pivotal issue in the time of Jesus. Rather, the emphasis was on the attitudinal changes towards the things of God and humanity. Jesus did not make it a point of reference in his preaching during his earthly life. He very much emphasised on the love of God and one's neighbour, which he saw as a weapon against injustice in the society.

Moreover, Paul and other apostles worked assiduously in the propagation of the Gospel, as directed by Jesus for the sole 
aim of converting souls. The emphasis was not on tithe as the case may be with contemporary preachers in Christianity but to work according to their callings.

Today, tithe is the main ingredient of the gospel message and preaching amongst some men and women of God, which started with fervour in the Pentecostal churches before creeping into the mainstream churches. It is worrisome that the intention of these preachers is not on converting souls but on the material gain of Christianity. This has made Christianity look like a business venture, which has attracted many with dubious character to join the bandwagon. As if that is not enough, they conjure up a thought and came up with sowing of seed, which does not tally with different quotes in the Bible.

\section{Seed sowing}

Sowing of seed, as understood by Christians and the preachers, is the belief that one can provoke God to do his bidding when a large amount of money or property is given in the name of God. It is a belief amongst the Nigerian Pentecostal worshippers and of recent mainstream church worshippers that their pastors can influence God to help them get a high position in Government (Johnson 2010:18). The members of these churches in high public position donate a huge sum of money and other valuables like expensive cars to the pastors to help motivate the pastors to ask God to protect the donors' position (Obijiofor 2013:35).

The unfortunate thing about sowing of seed is that most times the said pastor would be the person to tell these unsuspecting and innocent members what to sow as a seed in order to gain approval from God. Hence, the quote '... I will not offer burnt offerings to the Lord my God which cost me nothing' (1 Sm 24:24AMP). This is another way of siphoning the merge income of the members as many of these members would end up being poorer or wretched. Looking at the whole scenario, the implication of this is that Christianity is like a jackpot, which one can bet with either his money or property in anticipation of a bigger win. This does not augur well with the tenet of Christianity, the primary aim of which is a means of succour to people in every situation. Christianity preaches love, which is lacking in the minds of these preachers who are centred on materialism.

\section{The activities, attitude and their inordinate ambitions}

In Nigeria, tithing and seed sowing is currently a well-known practice in the church. The debate on the teachings of tithe and seed sowing has captured centre stage in present-day public spaces. Some people kick against the teaching of tithing and sowing seed, insisting that they are means of extortion, whilst others maintain that paying of tithe and sowing seed is a biblical and important doctrine for the church. Speaking against the teaching of tithe and sowing seed, daddy freeze, a social media activist argues that tithe is a false doctrine for Christianity, insisting that he have proven it scripturally several times with examples that Jesus Christ and his disciples never collected tithes (Vanguard 2018). However, Christian leaders insist that paying of tithe is a very essential part of Christendom, and that every believer is expected to give to the Church $10 \%$ of his or her earnings (Irekamba 2016). In support of this argument, Kitause and Achunike (2013), in their research work, revealed that:

[T]ithing is ordained by God while seed sowing is probably based on inference and personal revelations of its originators and practitioners across the globe, and therefore, remains Pentecostals' creation in Christendom. (p. 16)

It is good to note that there are no churches that reject tithes or seed sowing from its members.

In many churches, tithe and offering have become an instrument of exploitation and milking people of their finance for economic gains. People are made to believe that once they come to church and sow a seed with their money, they will become wealthy. This has changed some peoples' primary aim of going to church, as little or no emphasis is placed on how one should acquire this wealth in a manner and form that is right, and avoid all illegal and corrupt means of acquiring wealth (Onwuka 2017). Adherents are made to know that as they bring out more money and sow quality seeds, the more they receive the blessings of God. Thus, in many Pentecostal churches, they have names for different kinds of seed, such as prophetic seed of offering, receiving the seed of faith, a prophetic seed of faith, a personal seed of faith, financial seed, open door seed and other kinds of seed. In some cases, they ask people in need of one thing or the other, such as people seeking for the fruit of the womb, people seeking for employment, people seeking for a contract, people seeking for admission into university and people seeking a financial breakthrough to come for prayers with their seed (Iheanachor 2009:107; Magbadelo 2004:16; The Sun 2019). They make adherents believe that sowing a seed and paying tithe is a sacred ritual that makes God to solve one's problem and rain his blessings on a person. In some cases, adherents are made to believe that curses, such as poverty and other problems of life, will befall any person that do not sow seed and pay tithe (Asamoahgyadu 2018:23).

The emphases placed on tithe and seed sowing makes it seems as one is buying his or her way to gain God's blessings. In support of this claim, Waapela, cited in Iheanachor (2009:107), reveals that people are 'asked to pay money ranging from N50 000 or bring cars' as a seed to their pastors who will look straight to the face of their members and tell them their problem. This attitude by some men of God (pastors) in some churches in Nigeria has made it seems as if one can only access God's blessing with money. According to Olamide (2019), this attitude is likened to the condemnable attitude of Simon Magus in the Bible when he offered money to gain God's gift from Peter and John. However, Peter told him to perish with his money, and that God's blessing and 
gift cannot be acquired with his money (Ac 8:20). In addition, it is clear from the Bible that the blessings of God cannot be secured by money as Jesus Christ, whose teachings and ways Christians follow, healed many people from all kinds of sickness and diseases and even fed the people without collecting money from them. Jesus Christ affirms this when he states that more emphasis should be placed on issues, such as living right in accordance with the law, mercy and just judgement more than tithe in his words in Matthew 23 that says thus:

Woe unto you, scribes and Pharisees, hypocrites! for ye pay tithe of mint and anise and cummin, and have omitted the weightier matters of the law, judgment, mercy, and faith: these ought ye to have done, and not to leave the other undone. (v. 23 King James Version [KJV])

From the aforementioned sentence, one would agree that the activities, attitude and inordinate ambitions of many churches in Nigeria towards tithe and seed sowing seem to differ from the teachings and ways of Jesus Christ who is the founder of Christianity. Thus, churches seem to be more interested in getting money out of adherents more than emphasising on the moral and Godly ways of living. In support of the assertion, Diara et al. (2020:4) revealed that because of much emphasis placed on money in the church, 'people are no longer taught Kingdom principles as Jesus taught his disciples'. The effect can be observed in the high rates of corrupt, crime and immoral life of Nigerians who always troop into the churches on Sunday with no influence of the church to show, as they continue with their corrupt, criminal and immoral life (Diara \& Mokwenye 2019:3; Ngwoke 2020:18). Therefore, the church is expected to focus more on how to influence the people with the right attitude as Jesus did, which will make their adherent live out the moral life with the positive effect, such that it will bring about the reduction of crime rates and corruption in Nigeria.

\section{The implication of tithe and seed sowing on contemporary Christianity in Nigeria}

Although the Bible supports tithe and seed sowing, however, some preachers' attitude of using tithe and seed sowing to extort adherents has become the trend in most churches here in Nigeria. Supporting this claim, Diara and Mokwenye (2019:2), in their work, observed that many churches in Nigeria are focused on the economic gain by exploiting and manipulating the people financially. Therefore, many men of God have become a burden to their members, with less emphasis on their obedience to God's principles. Thus, some pastors and prophets psychologically exploit their adherents to believe that by giving a substantial amount of money in the name of sowing seed, their problems would be solved. Unfortunately, the person may remain the same as he or she came or the situation would be compounded. The phenomenon has many implications for both the church and society. Therefore, this article discusses some of the implications of tithe and seed sowing on contemporary
Christianity in Nigeria. As tithe and seed sowing have biblical support, and hence, the implication will be classified into positive and negative implications.

\section{Negative implications}

The negative implications of tithe and seed sowing on the church and the entire Nigerian society are worrisome as it has directly or indirectly promoted fraud and corruption in Nigeria. They are too numerous to outline and analyse in one study. Therefore, this article discusses some of the major negative impacts of tithe and seed sowing on the church and the Nigerian society, at large.

\section{Encouragement of corruption and fraud in the church and society}

In Nigeria, today, the church has become a money-making venture as many men of God (the priest or pastors) turn it to be. They focus on how to make money from adherents more than saving souls, which makes them lay so much emphasis on tithe and seed sowing. Thus, the teachings of tithe and seed sowing by some churches place this as a condition for one to prosper financially. The pastors anchor their monetary exploitation from their devotees on the basis of scripture, which they portray as a non-negotiable financial obligation. One of the cases includes the message of a renowned Pentecostal priest Rev. Dr Uma Ukpai during a crusade in Lagos, in November 2002, when he admonished the people to come and sow a seed of faith, as it is a condition for them to receive divine blessings from God, which include financial and material blessings (Magbadelo 2004). He also stated that '[i]f you are not a giver today, you shall be a beggar tomorrow', thus, instigating fear in the mind of those who may not want to give.

The exploitation of adherents' finance and manipulation of their mind have become the instruments employed by many churches. They exploit the people by twisting the religious teachings in the Bible such as the message from Jesus Christ in Mark 4:24 KJV '... with what measure ye mete, it shall be measured to you ...' for economic gains. Supporting this assertion, Nwanganga (2017:4) argued that currently, most churches in Nigeria no longer preach hard work but rather, they have drifted their teachings with a focus on the economic gain as they have now turned Christianity into a massive business venture marred by mischief. This approach has relegated the main purpose of the church, which is to win souls as commanded by Jesus in Matthew 28:19. Arguing in the same line, Ngwoke (2020:18) wrote about how the churches in Nigeria seems to have changed from its main role of influencing the mind of the people with its religious teachings, 'which will make people conscious of God's reward to those who live a corrupt-free life and God's punishment to those who live a corrupt and immoral life'.

This has contributed to the thriving rate of corruption and fraud in the church and in the society at large as seen in the life of many people, including the church leaders or priest. Thus, 
people who acquire wealth through illegal, corrupt and fraudulent means are praised and blessed by the church. Supporting this claim (Diara et al. 2020:3), agrees that the emphasis on tithe and seed sowing has encouraged corruption amongst the politicians as they now believe that God is only interested in their tithes and offerings. From this assertion, one would agree that the church has contributed to the 'get rich quick syndrome', which drives mostly the youth to the attitude of getting rich by any means. Thus, fraudulent and corrupt means of acquiring wealth have become the order of the day.

\section{Contributes to the increasing poverty rate in the church and society}

Leveraging on the word of Mbitu, Nigerians are highly religious. Christianity has become the opium of Nigerians. Thus, as Nigerians seek help from the church for a financial and spiritual breakthrough, they become a victim in the hand of some men of God who end up extorting them. As most Nigerians go to churches seeking spiritual help to escape from the clutches of poverty and sickness, the so-called Godcalled and self-called pastors now capitalise on the faith of these innocent Christian adherents and indirectly extort from them. Some people are convinced by their church or pastor to sow their first salary as a first fruit seed, breakthrough seed, miracle seed and many other kinds of seed for God to bless them financially or with material blessings in return. In one of such cases, a lady from a low-income family narrated to her employer how she wanted to give her first salary to the church as her first seed. Sharing her intention to the employer, she said:

[A]unty, I want to sow my salary as my first seed in church. I couldn't gain admission into university last year, despite meeting the cut-off mark of the post unified Tertiary Matriculation Examination (UTME). This is my first salary ever, I want to tie my admission to it as a seed. (The Sun 2019)

In some churches here in Nigeria, some preachers proudly announce the amount of money to be sowed as fruit for each level of blessings. It is unfortunate to note that many Nigerians have been pushed to the poverty line as they fall victim to the extorting means played by some pastors. Analysis from the research work of Okosun (2018:89) revealed that preachers enrich themselves largely through their congregation, citing the situations where many Nigerians are living in poverty but their pastors are living a rich and flamboyant lifestyle.

\section{Contribute to the decline of morality in the church and society}

The church, which is known from the teachings and life of Jesus for its high moral standards, has lost its moral standards and value in our contemporary Nigerian society because of the attitude of church leaders and ministers. The men of God (pastors or priest) whose teachings focus on tithe and seed sowing to their adherents without teaching them the part of the gospel that condemns immoral and unlawful means of acquiring wealth are partly responsible for the decline in moral standards. They do not condemn or speak out against immoral life found in their adherents because of the fear of losing them, which will also make them lose their tithe and seed. Diara and Mokwenye (2019:3) underscored this phenomenon when they argue that the effect of this phenomenon is linked to the springing up of 'all kinds of churches, where the so-called pastors encourage people to come as they are because God looks at the heart and not the outward appearance'.

Therefore, the church uses the falsehood that one will become rich once he or she comes to church and sow a seed to draw large members to their church who have only come there to ask for financial blessings in whichever way, which include immoral means. Hence, prostitutes, arm robbers and corrupt politicians come to church and sow seed with their ill-gotten money, expecting that their seed will in return lead to more money from God even from their illegal and immoral source. The church fails to teach them the true gospel of Jesus, which is free from an immoral and corrupt lifestyle. Thus, this attitude of the church has contributed to the decline of morality in the church and society. Nwadialor and Umeanolue (2013:38) posited that churches spring up in large numbers in every street and corner, but the hearts and minds of the worshippers are far away from God as they are not influenced by the right moral teachings of the church, leading to a moral decline.

From the assertion of Nwadialor and Umeanolue, one can agree that the church has contributed to the decline of morality in our contemporary society as churches keep on increasing in numbers of adherents with no evidence of the positive influence of the church on these adherents. Therefore, one can agree that this contributed to the moral decline we see in our society as they have failed in its role of modelling the life of the people with the teachings of the gospel of Jesus Christ, which is free from immoral and corrupt lifestyle because of their focus on financial gains. Supporting this assertion, Ukpe (2019:122) maintained that the preachers who focus their teachings on prosperity to their adherents without teaching them the legitimate means of acquiring wealth are partly responsible for the decline in morals and virtues.

\section{Contributes to the increasing crime rate in society}

The men of God (pastors or priest) whose teachings to their adherents focus on God's blessings to those who pay tithe and sow seed without teaching them the part of the gospel that condemns all forms of criminal ways of life, which includes criminal means of acquiring wealth, have contributed to the high crime rates in our society. Most Nigerians, especially the youth, have been carried away by the preaching of God's blessing to anyone that pays tithe and sow seed. Thus, they are involved in all kinds of criminal activities for their source of income, with the belief that their business has been blessed by God as they pay tithe and sow seed. In order to support this claim, Kitause and Achunike (2013:17), in their compact research, posited that people carry out all sorts of criminal actions, which include misappropriating money in their places of work to pay tithes 
and sow seed. They further assert that some people pay tithes and sow seed just to show off, or to boost their ego and to uphold their fame in the church. This is because most of the prosperity preachers in Nigeria have drifted from the teachings of holiness and now focus on the teaching of materialism. This has, in a great way, made some people to be engaged in all forms of illegal and fraudulent businesses, with believing that once they are bringing in their tithe and sowing seed, God will make their business more successful. Thus, many youths are now involved in all sorts of illegal and criminal businesses, such as ritual, yahoo business and other cybercrime activities, to mention but a few.

\section{Positive implications}

The positive implications of tithe and seed sowing on the church and the entire Nigerian society irrespective of its numerous negative implications are the following.

\section{Support for the ministries of the church}

One of the positive implications of tithe and seed sowing on contemporary Christianity in Nigeria is its support for the ministry of the church. The money raised from the tithe and seed sowing serves a great purpose in running and maintenance of churches. One of the main purposes of tithe comes from the old testament, as God commissioned a certain group of people in Israel (the tribe of Levi) to take charge of the church ministry, which include taking care of the church and providing spiritual leadership for the Israel nation $(\mathrm{Nm}$ 18). With these responsibilities, God instructed the rest of Israelites to pay in the tithe of their increase to provide support for the priests. The Bishop of the African Church, Diocese of the North and Abuja, Rt. Rev. (Dr.) Peter Ogunmuyiwa in an interview captured by the Guardian newspaper said that part of the money from the tithe is used for payment of pastors' salaries (Irekamba 2016). Therefore, tithe and seed sowing serve as a source of income to support the ministries of the church, especially to the priest and missionaries, income for the day-to-day running of the church and income for expansion of the church. Supporting this claim, Kitause and Achunike (2013:16) presented some significant reasons for tithe and seed sowing such as to bring income in God's house so that the priests serving God will have the means to take care of their needs, to take care of work in the church and to help in the maintenance of the ministry.

\section{Promotes infrastructural development of the church}

Today, many churches in Nigeria are witnessing much infrastructural development. The evidence is seen from the recent magnificent buildings used as church auditoriums and worship centres. This is achieved through offerings and seed sowing that are specially organised to build the church. Supporting this claim, Kitause and Achunike (2013:15), in their work, deduced that some churches organise special offering and seed sowing for the church-building project. Most of the fast-growing Pentecostal churches in Nigeria were able to build their church branches in several locations, including remote rural areas through funds raised from tithe and seed sowing. Some of the churches now build megachurch auditoriums from the money raised through tithe and seed sowing.

\section{Serves as a means of tackling poverty}

The role of the church in supporting the poor is a significant positive implication of tithe and seed sowing in contemporary churches in Nigeria. It is an unarguable fact that many Nigerians are living below the poverty line. A report from the National Bureau of Statistics (2020a:5) shows that $40.1 \%$ of Nigerians, which is about 82.9 million Nigerians, live below the poverty line. Most of these people identify with one a church. Thus, the church takes the responsibility for supporting the poor amongst them. Fehintolu and John (2016:4), in their work on the role of the church in National development, posited that the redeemed Christian church has established programmes for the acquisition of skills for poverty eradication in the society in many parts of Nigeria. In the same line, Pastor Lazarus Muoka, General Overseer of the Lord's Chosen Charismatic Revival Ministries, Worldwide said that tithe and offering are used for members' welfare (Irekamba 2016). This is supported in Deuteronomy $14(\mathrm{KJV})$ :

At the end of three-year, thou shalt bring forth all the tithe of thine increase the same year, and shalt lay it up within thy gates: And the Levite, (because he hath no part nor inheritance with thee,) and the stranger, and the fatherless, and the widow, which are within thy gates, shall come, and shall eat and be satisfied; that the Lord thy God may bless thee in all the work of thine hand which thou doest. (vv. 28, 29)

Here, the Bible has clearly stated the class of people who should be supported from the proceed of the tithe, which includes the priest, the fatherless and the widow. From the context of this verse, we can classify the fatherless and the widows as the poor because of the absence of the father or the husband who is supposed to cater for the family. Thus, their source of income is affected, which is the same case with the poor.

\section{Creation of employment opportunity}

Because of the rate of poverty, hardship and unemployment in Nigeria, many unemployed people have seen the church as a business opportunity to make money from adherents through tithe and seed sowing. Statistic from the National Bureau of Statistics (2020b) shows that $30 \%$ of Nigerians are unemployed. The high rate of unemployment has in no doubt led some people to joining pastoral work. In support of this assertion, Nwanganga (2017:4) wrote about how many frustrated Nigerians resort to pastoral work without being called by God because of their frustrated effort of job seeking without gaining meaningful employment. Thus, they devise ways with a focus on exploiting their adherent with different kinds of seed sowing. For them, the church is a business venture. Thus, any strategy needed for income to keep flowing into the church is employed. This is why many graduates who have failed to gain employment resort to 
opening churches (Diara et al. 2020:1). In addition, they employ staff, such as accountant and other staff. In Nigeria, today, some churches have opened schools for investment purpose from the church income, which also leads to employment opportunities.

\section{Recomendations}

1. The Christian Association of Nigeria (CAN), the Pentecostal Fellowship of Nigeria (PFN) and other Christian bodies should come together to address and manage the wrong approaches in the use of tithe and seed sowing, as it has been observed that the unwholesome phenomenon is negatively affecting the church and Nigerian society at large with its promotion of corruption, fraud and crime, to mention but a few.

2. Preachers should preach the gospel with decorum as it were in the Bible so that its influence on Nigerians will bring about a reduction in crime, corruption and other immoral activities in Nigeria.

3. Christian Association of Nigeria and PFN should partner with the Nigerian government in monitoring and punishing preachers or churches that are found using tithe and seed sowing wrongly as it has been observed in the article that some preachers use tithe and seed sowing as a means of extortion.

4. Preachers should rise to their God given responsibility by laying more emphasis on the teachings and influencing their adherents with teachings that promote moral values, acts of righteousness, hard work and patience, which will yield the fruit of prosperity.

\section{Conclusion}

Tithe and seed sowing are subjects of intense debate of recent years. Many have questioned the genuineness of tithe and seed sowing amongst the Christians. The inference is that it is a biblical injunction that people must pay tithe and sow seed. Failure to observe these is seen as an act of disobedience that comes with its consequences. Therefore, it is imperative to do so for the blessing that comes from them.

The issue is, however, not on the observation of tithe and seed sowing amongst Christians, but the renewed interest and emphasis by the preachers of Christianity. This is viewed with suspicion as the ideas have turned to a way of making money in modern times. This research study has shown how the activities, attitude and inordinate ambition of some men of God inform people's choice of opening churches. Many factors are attributed to the attitude and activities of these preachers. Poverty, unemployment, the socio-economic situation in Nigeria and ignorance, to name a few, have contributed to the present attention given to tithe and seed sowing amongst these preachers. The search for solutions to many problems that are confronting people on a daily basis opens the door for these preachers to actualise their dream of affluence. This has led to the unprecedented wave of materialism that is ravaging society. The overemphasis on material blessings without a corresponding emphasis on winning souls may, therefore, be counterproductive in Nigeria. The total outcome of this phenomenon has affected our society in all ramifications as it contributes to the high corruption rate. Thus, the church receives and beat drums of praise for corrupt people who brings in their corrupt gotten money to the church in the name of seed sowing, thereby, encouraging corruption. They lay more emphasis on tithe and seed sowing with little or no emphasis on moral and right values, which is based on the life and teachings of Jesus Christ.

It is true that the negative implications of tithe and seed sowing have tainted Christianity as the money-making venture; yet, many have benefitted from the proceeds. The proceeds from tithe and seed sowing, as discussed in this article, have helped in poverty alleviation and some other developmental projects in the church, which is of great importance to the members. Nevertheless, one has to understand that the biblical injunction of tithe is not the same as the practice of tithe amongst the Christians in Nigeria today. All these calls for an urgent appraisal of the present emphasis and use of tithe and seed sowing in contemporary Christianity in Nigeria by all stakeholders. If the gospel preachers should preach the gospel with decorum and as it were in the Bible, its influence on Nigerians will bring about a reduction in crime, corruption and other immoral activities in Nigeria. The emphasis should be more on the acts of righteousness, hard work and patience, which will yield the fruit of prosperity. This will go a long way of eliminating corruption, insecurity, killings of innocent people and other ill activities in the society.

\section{Acknowledgements}

The authors sincerely appreciate the efforts of Prof. Ernest van Eck and the people who assisted in reviewing and editing this article.

\section{Competing interests}

The authors declare that they have no financial or personal relationships, which may have inappropriately influenced them in writing this article.

\section{Authors' contributions}

G.N.A., P.N.N. and O.G.C. contributed equally to this article.

\section{Ethical considerations}

This article followed all ethical standards for a research without direct contact with human or animal subjects.

\section{Funding information}

This research study received no specific grant from any funding agency in the public, commercial or not-for-profit sectors. 


\section{Data availability}

Data sharing is not applicable to this research article as no new data were created or analysed in this study.

\section{Disclaimer}

The views and opinions expressed in this article are those of the authors and do not necessarily reflect the official policy or position of any affiliated agency of the authors.

\section{References}

Ademiluka, S.O., 2020, 'A study of Malachi 3:8-12 in relation to tithing in some churches in Nigeria', Old Testament Essays 33(2), 285-305. https://doi. org/10.17159/2312-3621/2020/v33n2a8

Appau, S. \& Mabefam, M.G., 2020, 'Prosperity for the poor: Religion, poverty and development in sub-Saharan Africa', in Sefa Awaworyi Churchill, Ed. Moving from the millennium to the sustainable development goals, pp. 243-265, Palgrave Macmillan, Singapore.

Asamoah-gyadu, J.K., 2018, "'Your miracle is on the way": Oral Roberts and mediated Pentecostalism in Africa', Spiritus: ORU Journal of Theology 3(1), 5-26, viewed 22 December 2020, from https://digitalshowcase.oru.edu/cgi/viewcontent. cgi ?article $=1047 \&$ context $=$ spiritus.

Diara, B. \& Mokwenye, M.E., 2019, 'A critical analysis of the social implications of gospel merchandising among Nigerian Christians today', HTS Teologiese Studies/ Theological Studies 75(1), 1-6. https://doi.org/10.4102/hts.v75i1.5391

Diara, B., Onukwufor, M. \& Uroko, F., 2020, 'The structural advancement of religious communities and the commercialisation of the Christian religion in Nigeria' Theologia Viatorum 44(1), 1-6. https://doi.org/10.4102/tv.v44i1.31

Ekwunife, A.N.O., 1990, Consecration in Igbo traditional religion, Jet Publishers, Enugu. Fairclough, N., 2001, Language and power, pp. 1-259, Longman Inc., New York.

Fehintolu, O.T. \& John, A., 2016, 'An appraisal of the role of the church in national development: A case of the redeemed Christian Church of God in Nigeria', Multidisciplinary Journal of Research Development 25(1), 1-9, viewed 24 December 2020, from https://globalacademicgroup.com/journals/nard/Osamolu.pdf.

Iheanachor, N.N., 2009, 'A critical look at contemporary Nigerian Christianity', International Journal of Theology \& Reformed Tradition 1, 104-117, viewed 28 December, from https://www.academicexcellencesociety.com/a_critical_look at_contemporary_nigerian_christianity.pdf.

Irekamba, C., 2016, 'How do churches utilise the tithe members pay?', The Guardian viewed 15 December 2020, from https://guardian.ng/features/how-do-churchesutilise-the-tithe-members-pay/.
Johnson, B., 2010, 'The Pastorprenueur's fresh scandal', The News, 20 December, p. 18.

Kitause, R.H. \& Achunike, H.C., 2013, 'A historical discourse on tithing and seed sowing in some Nigerian Pentecostal Churches', IOSR Journal of Humanities and Socia Science 18(3), 7-19, viewed 02 December 2020, https://doi.org/10.9790/08371830719

Magbadelo, J.O., 2004, 'Pentecostalism in Nigeria: Exploiting or edifying the masses?', African Sociological Review 8(2), 15-29. https://doi.org/10.4314/asr. v8i2.23248

National Bureau of Statistics, 2020a, 2019 poverty and inequality in Nigeria: Executive summary, pp. 1-27, viewed 29 December 2020, from http://nigerianstat.gov.ng/ download/1092.

National Bureau of Statistics, 2020b, Labour markets, unemployment rate, viewed 29 December 2020, from https://nigerianstat.gov.ng/uploads/LaborQ32018.png.

Ndiokwere, N.I., 1990, Search for security: Freedom from sinister forces that threaten life in African society, AMBIK Press, Benin City.

Ngwoke, P.N., 2020, 'The place of religion in combating corruption in Nigeria', Journa of Church and State csaa058, 1-21. https://doi.org/10.1093/jcs/csaa058

Ngwoke, P.N., 2021, 'Religious manipulation and domestic violence within Christian homes in Nigeria', The International Journal of Religion and Spirituality in Society 11(1), 121-136. https://doi.org/10.18848/2154-8633/CGP/v11i01/121-136

Nwadialor, K.L. \& Umeanolue, I.L., 2013, 'Materialistic gospel message in contemporary Nigerian churches: A critique', Journal of Religion and Human Relations 1(5), 29-44, viewed 30 December 2020, from https://www.ajol.info/index.php/ jrhr/article/view/105150/95192.

Nwanganga, A.P., 2017, 'Church commercialization in Nigeria: Implications for public relations practice', Journal of Philosophy, Culture and Religion 28, 1-11, viewed n.d., from https://core.ac.uk/download/pdf/234694856.pdf.

Obijiofor, L., 2013, 'The sins of pastors', Daily Sun, 06 February, p. 35.

Okosun, D.E, 2018, 'Poverty, illiteracy cum prosperity theology: A quantitative study', International Journal of Social Sciences (IJSS) 8(1), 83-92.

Olamide, C., 2019, Sowing seeds, viewed 23 December 2020, from https:// olamidecraig.com/sowing-seeds.

Onwuka, A., 2017, 'ICYMI: Is another revolution imminent in the Nigerian church?', Punch, viewed 07 December 2020, from https://punchng.com/is-anotherrevolution-imminent-in-the-nigerian-church/.

The Sun, 2019, 'Why you should sow church seeds with wisdom', The Sun, viewed 07 December 2020, from https://www.sunnewsonline.com/why-you-should-sowchurch-seeds-with-wisdom/.

Ukpe, J.I.J., 2019, 'Prosperity gospel and its impact on members of selected Pentecostal churches in Makurdi metropolis', PhD thesis submitted to the Department of Religion and Cultural Studies, Benue State University, Makurdi, pp. 1-177, viewed 30 December 2020, from http://bsuir.bsum.edu.ng:8080/jspui/ bitstream/11409/455/1/UKPE\%20JAMES-THESIS\%20COMPLETE.pdf.

Vanguard, 2018, 'Tithe: Daddy freeze invites Adeboye for debate', Vanguard, viewed 05 December 2020, from https://www.vanguardngr.com/2018/12/tithe-daddyfreeze-invites-adeboye-for-debate/. 